\title{
$\alpha$-Trimethylsilylmethylamine Radical Cation in the Synthesis of Cyclic Amines and Beyond
}

\author{
Ganesh Pandey ${ }^{\star a}$, Debasis Dey, and Smita R. Gadre
}

\begin{abstract}
The evolution of chemistry associated with the photoinduced electron transfer (PET)-generated $\alpha$-trimethylsilylmethylamine radical cation cyclization to a tethered olefin to synthesize cyclic amine structural frame works is presented in chronological order. The importance of this interesting chemistry is demonstrated by the synthesis of several novel glycosidase inhibitors.
\end{abstract}

Keywords: $\alpha$-Amine radical · Glycosidase inhibitors · $1-N$-Iminosugars · Photoinduced electron transfer (PET) · $\alpha$-Trimethylsilyl methylamine radical cation

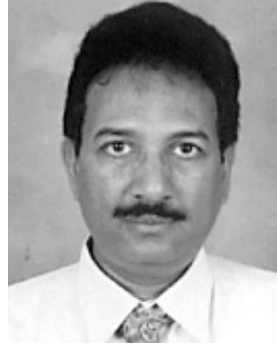

Ganesh Pandey (b. July 5th, 1954) obtained his $\mathrm{PhD}$ from Banaras Hindu University (under the direction of Prof. K. N. Mehrotra) in 1980. He then proceeded to Purdue University for postdoctoral study (July 1980-May 1983) in the group of Prof. H. A. Morrison. On returning to India, initially he joined (September 1983) Panjab University, Chandigarh as a 'Pool Officer' and within a few months moved to IICT, Hyderabad (May 1984) and established his research group at IICT. He once again moved to National Chemical Laboratory, Pune (July 1991) where he is pursuing his research interests in the area of developing new synthetic strategies involving radical ions as reactive species and natural products syntheses. He is recipient of some of the most coveted awards and honors from India.

\section{Introduction}

Nitrogen-containing heterocycles, such as pyrrolidines, piperidines, pyrrolizidines, indolizidines and quinolizidines are ubiquitous in a large number of naturally occurring alkaloids and pharmaceuticals which are endowed with diverse biological activities. ${ }^{[1]}$ Bicyclic amines such as pyrrolizidines, indolizidines and quinolizidines are also present in a large number of alkaloids isolated from amphibian skin, which are known to display a variety of biological activities. ${ }^{[2]}$ Another class of cyclic amines such as polyhydroxy piperidine, pyrrolizidine, quinolizidine and indolizidine constitute a distinct subclass, well known for their glycosidase inhibitory activities. ${ }^{[3]}$ Glycosidase inhibitors are particularly important in biochemistry and pharmacology owing to their potent application in a variety of carbohydratemediated diseases such as HIV, diabetes, hepatitis, cancer, and viral infections such as influenza. ${ }^{[4]}$ Therefore, developing an efficient synthetic strategy to synthesize substituted cyclic amines ${ }^{[5-9]}$ has engaged organic chemists over the years.
Although free radicals have evolved as the most significant reactive intermediates, due to their versatility, predictability and functional group tolerance, in the construction of carbocyclic structural frameworks, cyclization of corresponding $\alpha$-amine radicals, generated through conventional tributyl tin hydride from N-alkenyl-N(phenylthio)methyl amines, to obtain cyclic amines failed. ${ }^{[10]}$ This failure was explained by hypothesizing its reduced radical character due to electronic assistance of nitrogen lone pair to the radical (Scheme 1).

The above result led us to envision that if a trimethylsilyl group is attached to the $\alpha$-methylene position of a tertiary amine (9), a radical cationic species (10) generated on nitrogen would be delocalized between silicon and nitrogen through overlap between the filled $\mathrm{C}-\mathrm{Si} \sigma$-orbital and halffilled nitrogen orbital ${ }^{[11]}$ (Scheme 2) may undergo an $\mathrm{S}_{\mathrm{N}}$ 2-type cyclization process to a tethered olefin producing a cyclic amine system as shown in Scheme 2.

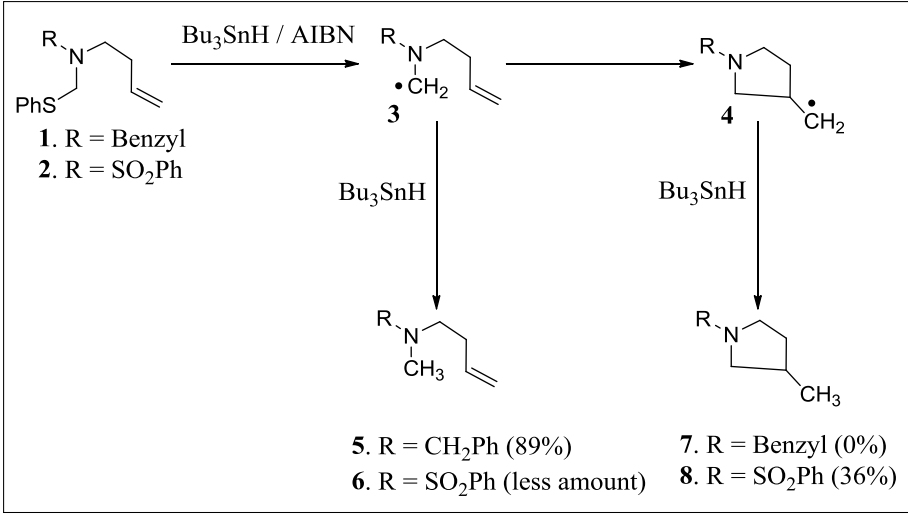

Scheme 1. Reactivity of the merostabilized radical. 


\section{Background of Concept}

The above concept emerged from our broad interest in radical ion chemistry in general and $t$-amine radical cation in particular. ${ }^{[12]}$ The amine radical cations can be generated efficiently through a photoinduced electron transfer (PET) process, using 1,4-dicyanonapthalene (DCN) as a light-harvesting electron acceptor, through the photoredox cycle shown in Fig. 1.

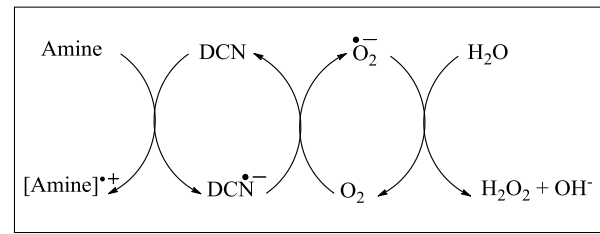

Fig. 1. Photoredox cycle for generating amine radical cations.

\section{Results and Discussion}

Our concept as outlined in Scheme 2 was vindicated when photolysis (450-W Hanovia lamp housed in a Pyrex vessel, $>300 \mathrm{~nm}, 2 \mathrm{~h}$ ), of a mixture of $\mathbf{1 4 a}-\mathbf{d}$ and 1,4-dicyanonapthalene ( $\mathrm{DCN})$ in iso-propanol produced cyclic amines $15 \mathbf{a}-\mathbf{d}$ in high yields ${ }^{[13]}$ (Scheme 3). The reaction was found to be successful on a variety of substrates and the entire amount of DCN was recovered at the end of the reaction.

The most favourable exo-cyclization product was formed in each case. Although, according to Beckwith's radical cyclization guidelines, ${ }^{[14]}$ cyclization of $\mathbf{1 6}$ was supposed to produce exclusively 17a, it produced a 1:1 diastereomeric mixture of 17a and 17b. Similarly 18 produced a $1: 1$ mixture of 19a and 19b (Scheme 4).

This unexpected cyclization result was explained by considering two easily interconvertible chair-like transition states (Fig. 2) where the energy barrier for interconversion was assumed to be very low. ${ }^{[15,16]}$ In order to support this explanation, cyclization of amines of type 20-23 were

2-Propanol
a) $n=1, R_{1}=H, R_{2}=C_{4} H_{9}$
b) $n=1, R_{1}=C H_{3}, R_{2}=C_{4} H_{9}$
c) $n=1, R_{1}=H, R_{2}=C_{2}-C_{6} H_{5}$
d) $n=2, R_{1}=H, R_{2}=C_{4} H_{9}$

Scheme 3. Generation and reaction of $\alpha$-trimethylsilyl-methylamine radical cations.

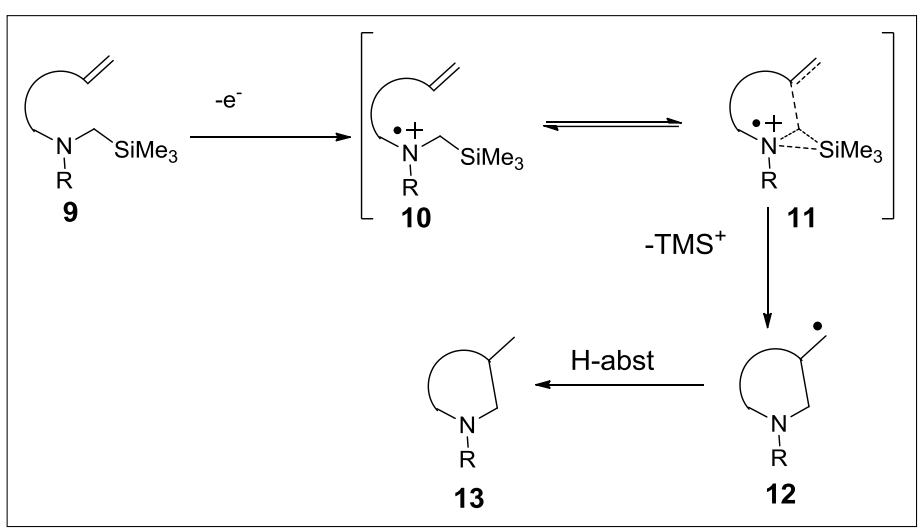

Scheme 2. Concept for the generation of an $\alpha$-trimethylsilylmethylamine radica cation.

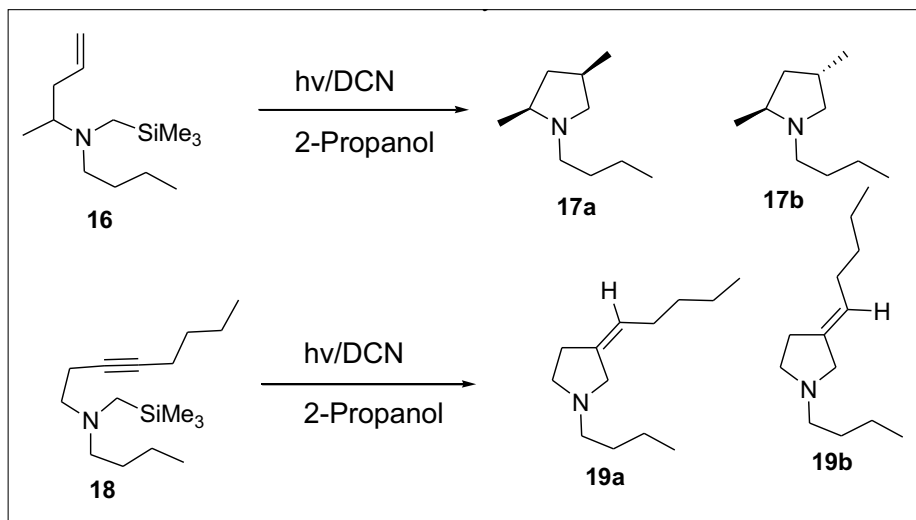

Scheme 4.

Stereochemical outcome of cyclization.

\begin{tabular}{|c|c|c|c|c|c|}
\hline & $\mathrm{hv/DCN}$ & & & & \\
\hline & 2-Propanol & & & & \\
\hline & & & $a: b$ & & Yield(\%) \\
\hline $20 n=m=1$ & & $24 a$ & $97: 3$ & $\mathrm{~b}$ & 90 \\
\hline $21 n=m=2$ & & $25 a$ & $0: 100$ & b & 88 \\
\hline $22 \mathrm{n}=1, \mathrm{~m}=2$ & & $26 a$ & $2: 98$ & b & 85 \\
\hline $23 n=2, m=1$ & & $27 a$ & $95: 5$ & $\mathrm{~b}$ & 87 \\
\hline
\end{tabular}

Scheme 5

Stereoselective construction of pyrrolizidine/indolizidine frameworks.

considered as in these cases interconversion would be restricted. The results are discussed in the next section.

\section{Stereoselectivity in the Cyclization of Cyclic Amines}

PET activation of cyclic amines 2023 produced the corresponding bicyclic amines 24-27 with an interesting stereochemical outcome. For example, the 1,5/1,6-stereochemistry was found to be dependent on the ring size being formed. In case of $\mathbf{2 0}$ and $\mathbf{2 3}$ where the new ring formed was five-membered, 1,5-cis stereo-

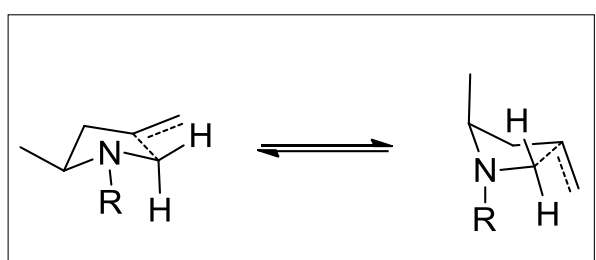

Fig. 2. Proposed transition state to explain the lack of stereoselectivity. chemistry was predominant whereas in the case of $\mathbf{2 1}$ and $\mathbf{2 2}$ where a six-membered ring is formed, 1,6-trans stereochemistry emerged (Scheme 5).

The 1,5-cis stereoselectivity for $\mathbf{2 4 a}$ and 27a was explained by invoking 'chairlike' transition states $\mathbf{2 8}$ analogous to the ring closure of 2-but-3-enylcycloalkyl radicals. Similarly, the emergence of transstereochemistry for $\mathbf{2 5 b}$ and $\mathbf{2 6 b}$ was visualized in terms of the 'chair-like' transition state 29 where effective overlap between the SOMO of the radical cation and olefin $\pi$-orbitals of olefin results in a 1,6-transstereochemistry (Fig. 3). [17]

This stereochemical outcome provided

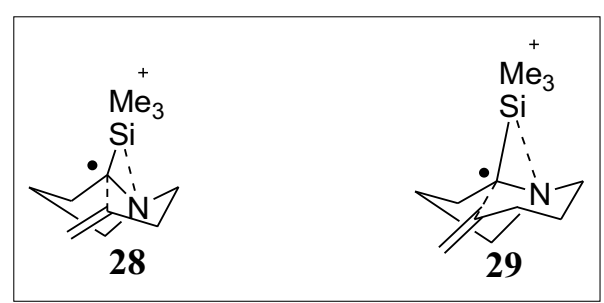

Fig. 3. Stereochemical rationalization. 
a general route towards synthesizing the azabicyclo[m.n.o]alkane skeleton, a prevalent structural framework in quinazolidine, indazolidine and pyrazolidine type of alkaloids. ${ }^{[18]}$ This strategy was utilized for the synthesis of racemic epilupinine ${ }^{[19]}$ (32) and isoretronecanol[20] (35) as shown in Scheme 6. The synthesis of these two natural products substantiated the stereochemical outcome of such cyclizations.

Having established an efficient general strategy for the synthesis of mono- as well as bicyclic amines, we envisioned extending this powerful cyclization protocol for the synthesis of polyhydroxylated cyclic amines which are endowed with diverse biological activities.

\section{Synthesis of Polyhydroxylated Piperidines}

Polyhydroxylated piperidines (Fig. 4) have attracted considerable attention as glycosidase inhibitors. ${ }^{[3]}$ Glycosidase inhibitors are carbohydrate analogues where nitrogen atoms have replaced one or more of the oxygen atoms. ${ }^{[21]}$ These alkaloids are sugar mimics and are widespread in plants and microorganisms. ${ }^{[22]}$ The activities of these compounds are rationalized on the basis of their similarities with the shape and charge of the postulated oxocarbenium ion intermediate formed during the glycosidic bond cleavage by glycosidase enzymes. ${ }^{[23]}$ Such molecules have also been demonstrated to be a tool for studying various biological functions of oligosaccharides. ${ }^{[24]}$ These classes of compounds have gained widespread interest due to the postulation that they can be used as therapeutic agents in various carbohydrate-mediated diseases ${ }^{[25]}$ like AIDS, diabetes, cancer and some viral infections like influenza.

Due to diverse and interesting properties associated with these polyhydroxylated cyclic amines, it was not surprising that their syntheses had attracted considerable attention from chemists around the globe. ${ }^{[26,27]}$ The main challenge in their syntheses has been to construct the aminomethyl group in the piperidine ring vicinal to a stereocenter starting with the carbohydrates. Many interesting syntheses are reported to overcome this problem but a general approach towards this obstacle is still lacking. Based on our current strategy of $\alpha$-trimethylsilylmethylamine radical cation cyclization, we envisaged a general strategy for the synthesis of both $\mathrm{D}^{-}$and L-type of $1-N$-iminosugars as shown retrosynthetically in Scheme 7. We anticipated that the fully functionalized piperidine skeleton could be obtained from the suitably placed exo-cyclic olefinic bond as in 41, easily obtainable by the PET cycliza-

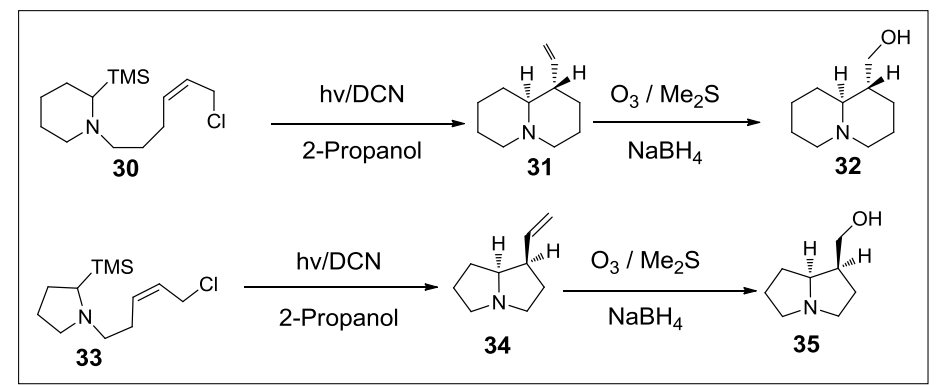

Scheme 6. Synthesis of epilupinine and isoretronecanol.
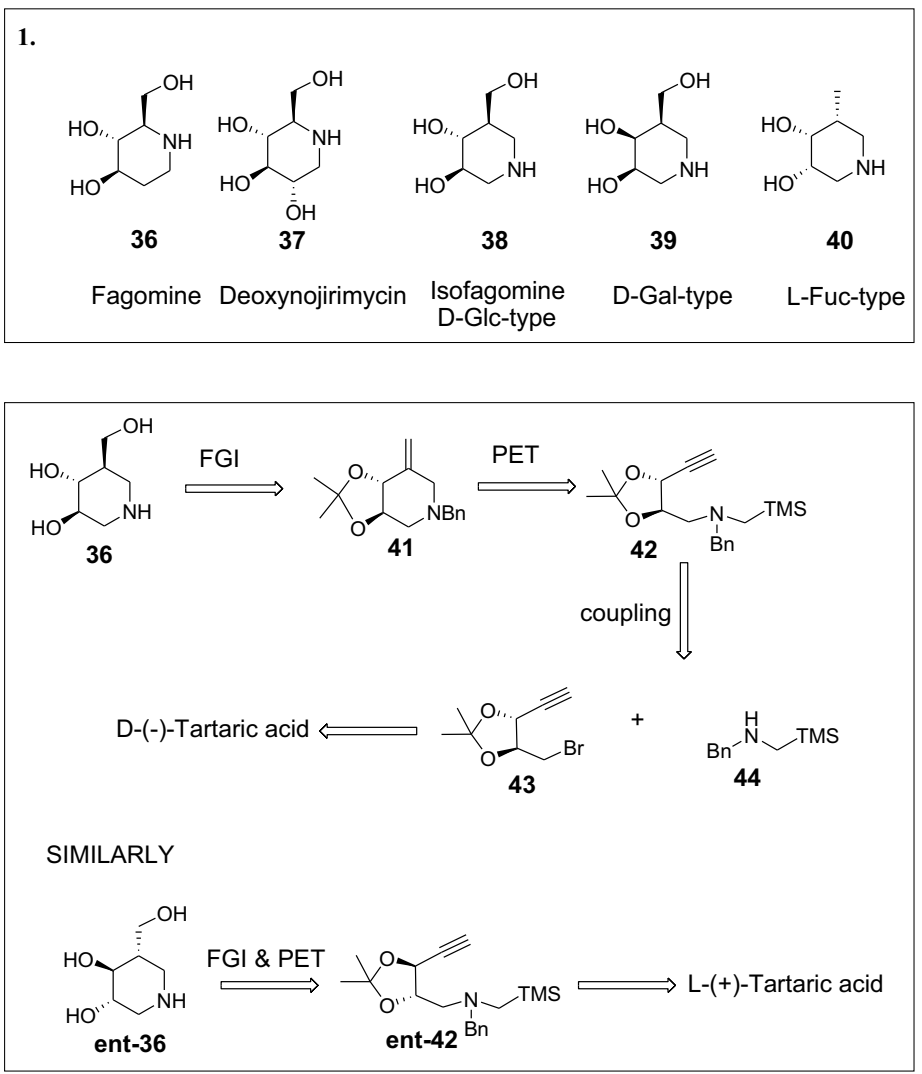

Fig. 4. Some important polyhydroxy piperidines.

Scheme 7.

Retrosynthetic breakdown of polyhydroxylated piperidines.

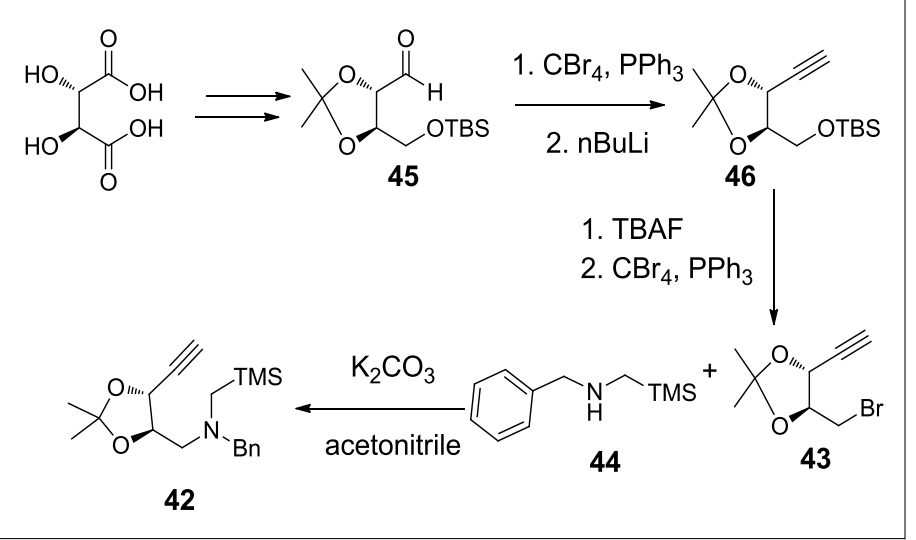

Scheme 8. Synthesis of the irradiation precursor for fagomine.

tion of $\mathbf{4 2}$. Compound $\mathbf{4 2}$ could easily be assembled from an abundantly found natural chiral resource.

The key irradiation precursor $\mathbf{4 2}$ was easily prepared either from $\mathrm{D}-(-)$ or from L-(+)-tartaric acid by following the simple synthetic steps shown in Scheme 8.

The PET cyclization of $\mathbf{4 2}$ delivered $\mathbf{4 1}$ which on hydroboration using 9-BBN furnished $\mathbf{4 7}$ as a pure isomer. The trans-stere- oselectivity for this reaction was assumed to arise due to severe steric interaction of the axial hydrogens of the acetonide rings with the bulky 9-BBN moiety (Scheme 9). Finally debenzylation of $\mathbf{4 7}$ by hydrogenolysis using Pearlman's catalyst produced (+)-isofagomine (36). Following a parallel protocol starting with L-(+)-tartaric acid, (-)-isofagomine (ent-36) was also synthesized. ${ }^{[28]}$ 


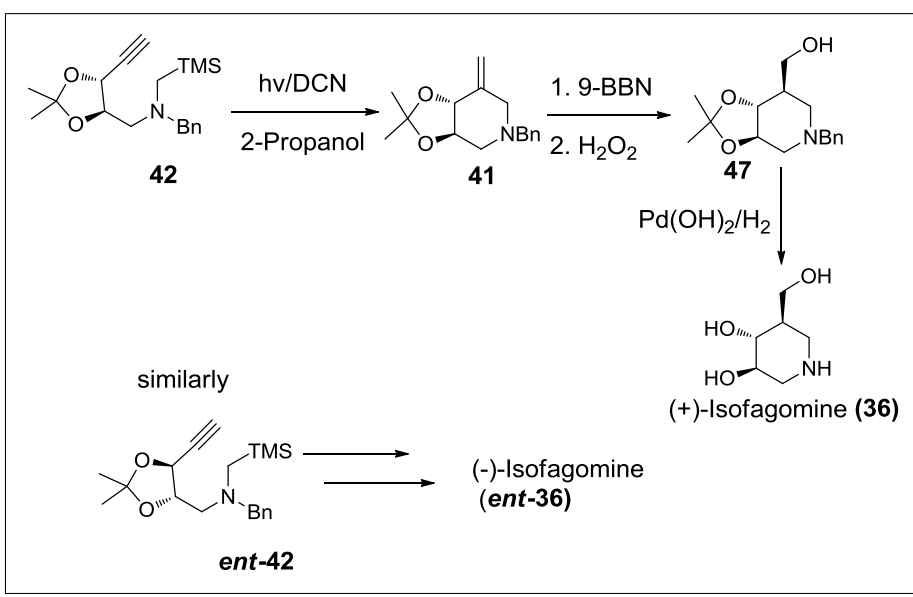

Scheme 9. Synthesis of (+)-isofagomine and (-)-isofagomine.

\section{Developing a General Approach for the Syntheses of 1-N-Iminosugars}

As the interest in azasugars grew rapidly, many interesting syntheses were reported.[29] Therefore, we renewed our interest in the pursuit of synthesizing and evaluating novel azasugars as glycosidase inhibitors. The chiral pool approaches which were available at that time lacked a general strategy towards various targets as each time the starting materials required small or overall modification making synthetic process tedious. ${ }^{[30,31]}$

A close assessment of all 1- $N$-azasugars uncovered a universal substitution pattern as shown in 48. Altering the stereochemical pattern at $\mathrm{C}(3)$ and $\mathrm{C}(4)$ and the nature of the substituent at $\mathrm{C}(5)$ would lead to the synthesis of most of these compounds. Therefore, a general precursor of type 49 was envisaged to serve the purpose provided the correct stereochemistry at $\mathrm{C}(3)$ and $\mathrm{C}(4)$ and desired functionalization at $\mathrm{C}(5)$ was possible (Fig. 5). This led us to propose two specific precursors $\mathbf{4 1}$ and ent-41 to synthesize D- and L-threo classes of $1-\mathrm{N}$-iminosugars, respectively.

Precursor 41 was utilized for the synthesis of two azasugars $50(\mathrm{~K} / \mu \mathrm{M}=$ 96, $\beta$-glucosidase $)$ and $51(\mathrm{~K} / \mu \mathrm{M}=30$, $\beta$-glucosidase) which showed promising glycosidase inhibitory activity when tested against $\beta$-glucosidase enzyme (Scheme 10).

The success in achieving the synthesis of these important azasugars encouraged us to visualize the possibility of synthesizing some of the most important 3,4,5-piperidine triols (52, 53 and 54, Fig. 6), isolated by Kusano and coworkers in 1995 from the extract of the plant Eupatorium fortunei. ${ }^{[32]}$ These polyhydroxy piperidines were considered as the derivative of deoxynojirimycin and they exhibited moderate to good glycosidase inhibitory activity. ${ }^{[33]}$ These compounds were also known to be used in Chinese and Japanese folk medicine as diuretic, antipyretic, emmenagogue and antidiabetic agents. These triols were ini- tially synthesized by Ganem et al. ${ }^{[34]}$ and other research groups. ${ }^{[35]}$

It was anticipated that precursor $\mathbf{5 6}$ and ent-56 would produce these polyhy- droxylated piperidines in a straightforward manner. For example, des(hydroxymethyl) deoxymannojirimycin (54) could be obtained by following the simple synthetic protocol as shown in Scheme 11. Synthesis of des(hydroxymethyl)deoxynojirimycin (53) was also accomplished by inverting the stereochemistry of the free hydroxy group of ent-60 by using standard Mitsunobu conditions (Scheme 12). ${ }^{[36,37]}$

\section{Synthesis and Evaluation of $\mathbf{C ( 6 )}$ Homologues of 1-Deoxynojirimycin as Specific Glycosidase Inhibitors}

By this time the potential of nojirimycin and its 1-deoxy analogues such as 1-deoxynojirimycin and 1-deoxygalactonojirimycin were established as strong $\alpha$ - and $\beta$-glucosidase inhibitors. ${ }^{[38]}$ Due to
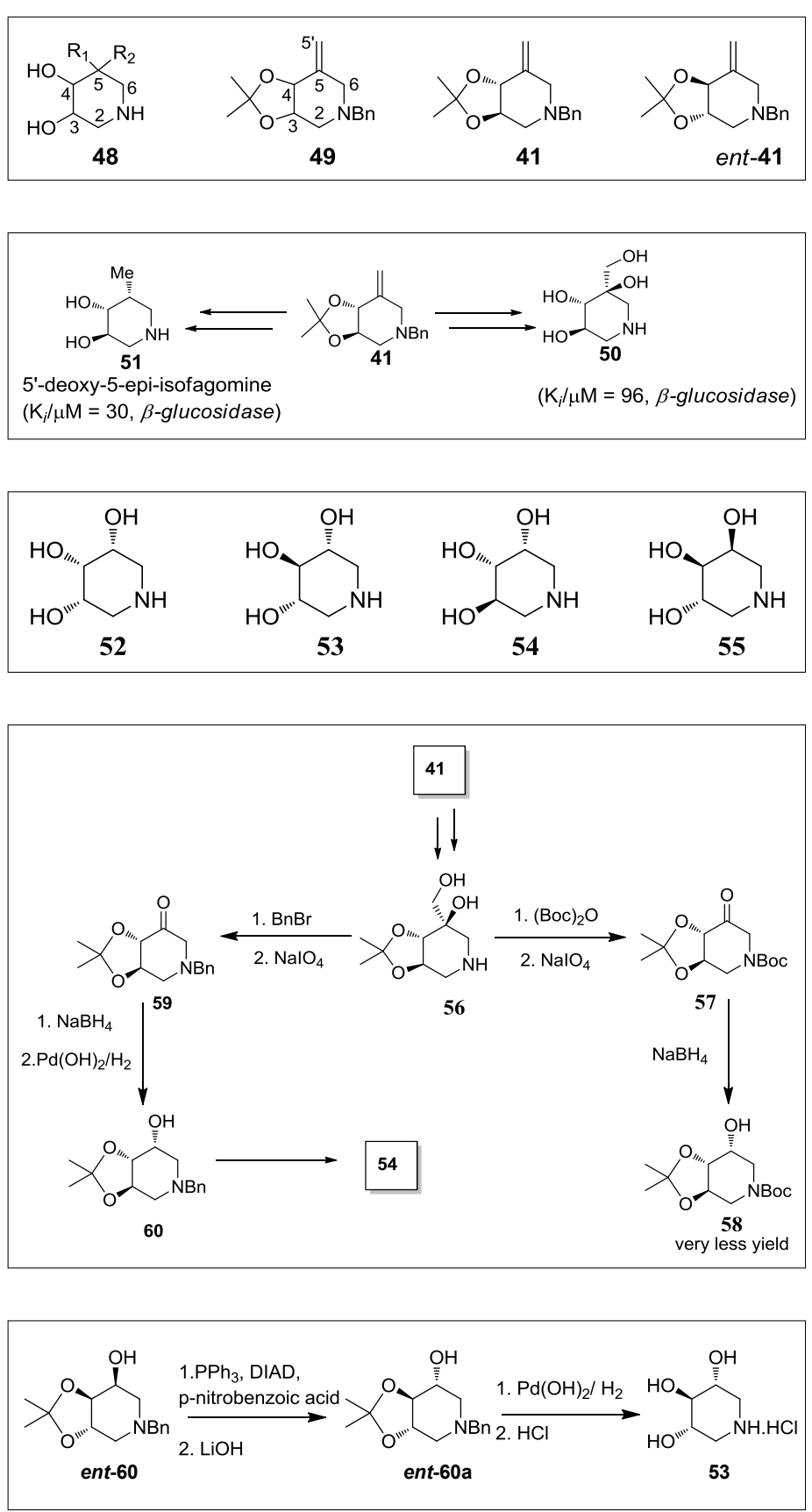

Fig. 5. General precursor of D- and L-threo classes of $1-N$-iminosugars.

Scheme 10.

Synthesis of 5'-deoxy-5-epi-isofagomine.

Fig. 6. Some of the most important 3,4,5-piperidine triols.

Scheme 11. The synthesis of the deoxymannojirimycin derivative.

Scheme 12 Synthesis of des(hydroxymethyl) deoxynojirimycin. 
intense research activities in this field, [39] two new azasugar-based medicines such as Miglitol (N-hydroxyethyl DNJ, Glyset or Diastabol) ${ }^{[40]}$ and Miglustat (N-nBuDNJ, Zavesca ${ }^{[41]}$ for the treatment of type II diabetes and Gaucher's disease, respectively, were introduced. In order to discover a molecule with better glycosidase inhibitory activities, intense research activities ${ }^{[41]}$ continued towards synthesizing homoazasugar derivatives with $\left(\mathrm{CH}_{2}\right)$-homologation at $\mathrm{C}(6)$ of 1-deoxyazasugars. However, the major challenge was to find a suitable route for the synthesis of polyhydroxy piperidines. As we had already established a novel route for the synthesis of polyhydroxy piperidine involving 41, employing PET cyclization of suitably substituted $\alpha$-trimethylsilylmethylamine, we turned our attention towards synthesizing $\mathrm{C}(6)$ homologues of 1-deoxy azasugars and evaluated their glycosidase inhibition activities.

Upon vigilant inspection it occurred to us that template $\mathbf{6 9}$, where the strategic exocyclic double bond would enable proper functionalization, could serve as a transition point for the synthesis of all these important azasugars (Fig. 7). This intermediate could be synthesized effortlessly by the cyclization of $\mathbf{7 0}$ employing our newly developed protocol. The irradiation precursor $\mathbf{7 0}$ could be assembled together through reductive amination of a chiral fragment 71 which can be obtained from L-(+)-tartaric acid and 72. Compound 72 was obtained from 3-aminopropanol utilizing known synthetic sequences. ${ }^{[35 a]}$

As anticipated the PET cyclization of 70 produced 69 (60\% yield) smoothly. Dihydroxylation of 69 using $\mathrm{OsO}_{4}$ produced $\mathbf{7 3}$ whose stereochemistry was confirmed through single crystal X-ray diffraction study (Scheme 13). Removal of all protecting groups generated $\mathbf{6 6}$. Furthermore, sodium periodate cleavage of 66 produced the corresponding bicyclic ketone which upon reduction with sodium borohydride produced $\mathbf{7 4}$ as a pure diastereomer. The stereochemistry was confirmed by $2 \mathrm{D}$ NMR spectroscopy. The removal of acetonide group using aqueous hydrochloric acid produced tetrahydroxy azasugar $65(\mathrm{~K} / \mu \mathrm{M}=1.7, \alpha$-galactosidase $)$. Enantiomeric azasugars of the same series were also easily synthesized using D-(-)tartaric acid.

While this study was in progress, it was noticed that there was increasing interest in the evaluation of glycosidase inhibitory activities of non-basic glyconolactams ${ }^{[43]}$ such as 75, 76 and 77 (Fig. 8). The original mechanistic rationale for inhibitory activities of these molecules was attributed to the involvement of their tautomeric iminol form, however, later detailed studies suggested the inhibitory activities were solely due to hydrogen bonding. ${ }^{[44]}$

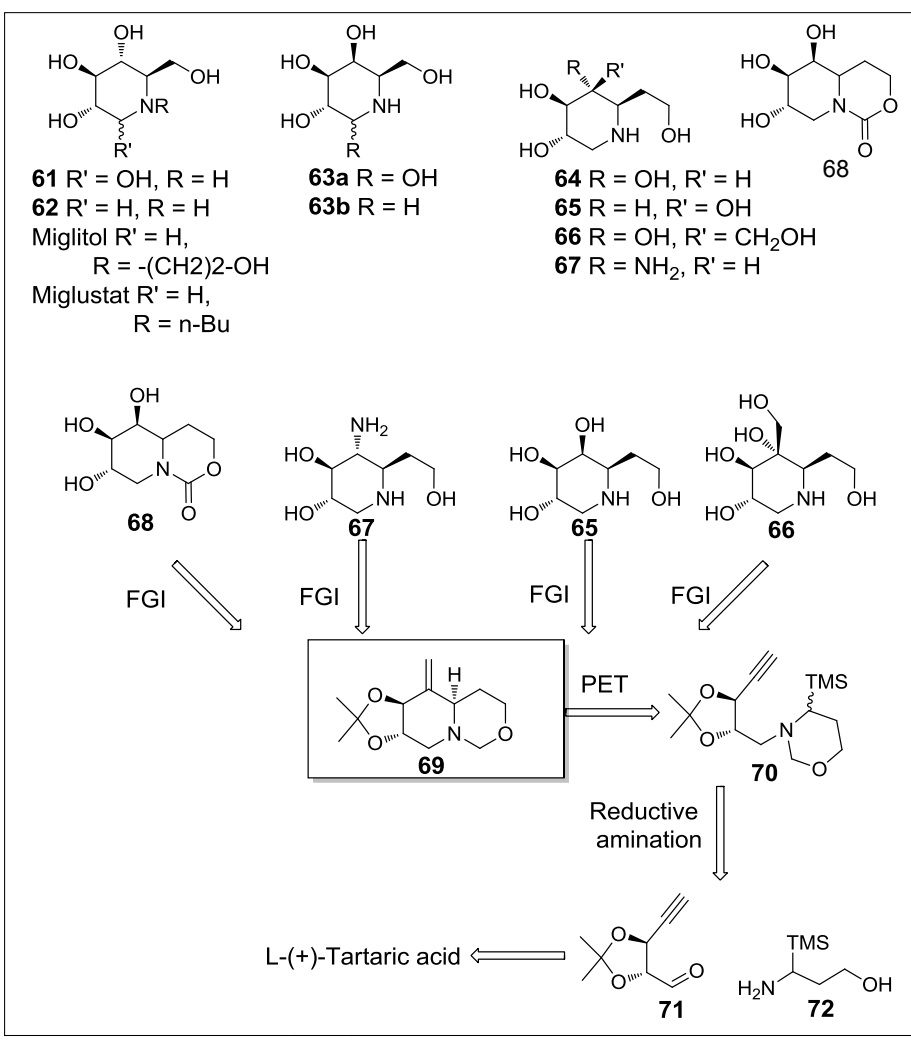

Fig. 7. Some important homologues of 1-deoxynojirimycin.

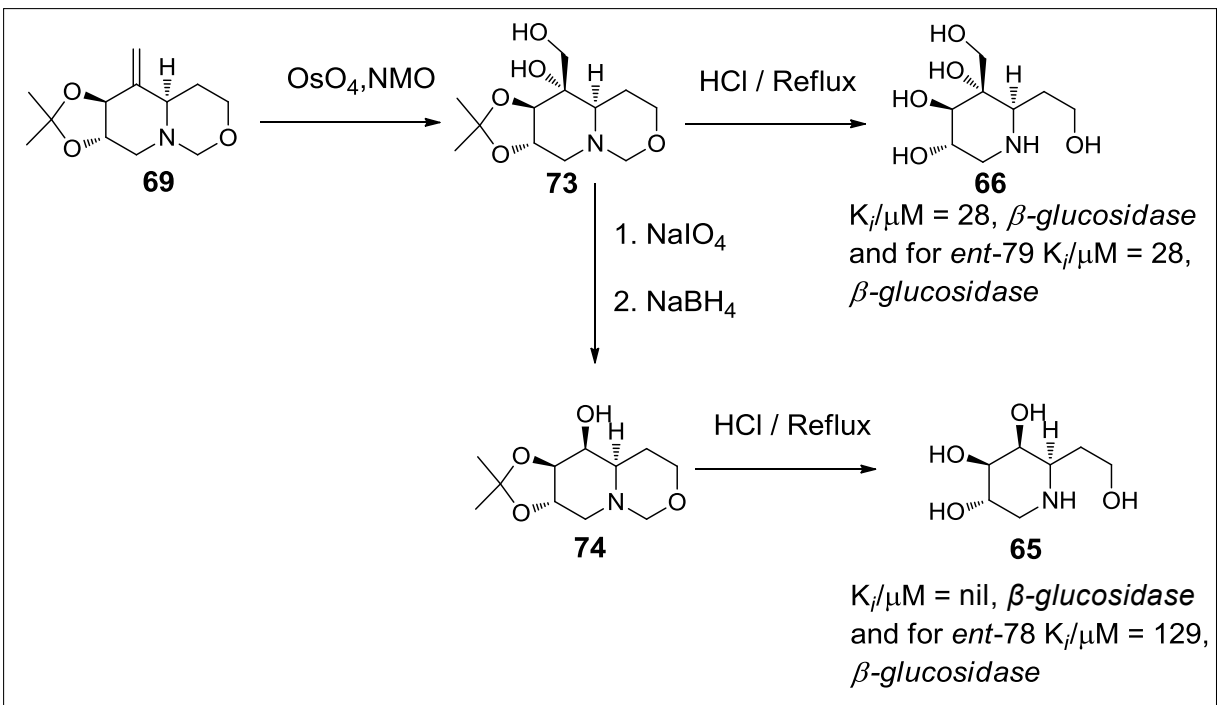

Scheme 13. Synthesis of azasugars.

Therefore, encouraged by these findings, we synthesized a new non-basic azasugar 68 from the intermediate $\mathbf{7 4}$ by following the reaction sequences outlined in Scheme 14. In continuation of our effort

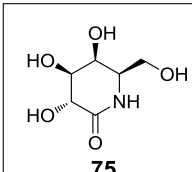<smiles>O=C1OCC2C(O)[C@H](O)[C@@H](CO)N12</smiles>

76

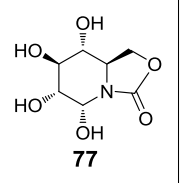

Fig. 8. Some non basic azasugars.

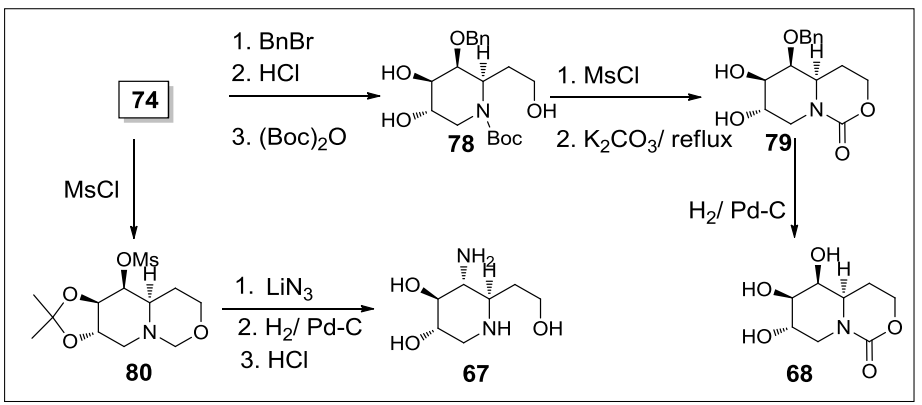

Scheme 14

Synthesis of non basic azasugars. 
to synthesize novel azasugars, molecule $\mathbf{6 7}$ having a more basic amino functionality was also prepared.

By following identical protocols and starting with D-(-)-tartaric acid, the entire enantiomeric series was also prepared and evaluated. Compound $\mathbf{6 6}(\mathrm{K} /$ $\mu \mathrm{M}=28, \beta$-glucosidase $)$ and its enantiomer ent-66 $(\mathrm{K} / \mu \mathrm{M}=12, \beta$-glucosidase $)$ showed modest specific inhibition against $\beta$-glucosidase and were found completely inactive for $\alpha$-glucosidase. Compound ent-65 $(\mathrm{K} / \mu \mathrm{M}=129, \quad \beta$-glucosidase $)$ also showed moderate specific inhibition against $\beta$-glucosidase. Inhibitory activities of other synthesized compounds were not so encouraging. ${ }^{[45]}$

\section{Synthesis of Conformationally Restricted Glycosidase Inhibitors}

Taking a clue from the previous studies, it was envisioned that the conformationally constrained polyhydroxylated $\beta$-lactamazasugar hybrid molecule of type $\mathbf{8 5}$ may be more potent as the $\beta$-lactam ring may compel the polyhydroxy piperidine ring to assume a nearly half chair conformation (mimic of the glycosidase inhibitor's transition state) and the carbonyl group may provide an additional $\mathrm{H}$-bonding site to the enzyme. The synthesis of $\mathbf{8 5}$ was accomplished from $\mathbf{7 4}$ through simple synthetic transformations shown in Scheme 15. Similarly its corresponding enantiomer was also obtained from D-(-)-tartaric acid. The C(10) methylated analogue 86 was also synthesized from $\mathbf{8 1}$.

The inhibitory activities of $\mathbf{8 5}, \mathbf{8 6}$ and ent-85 were studied against $\beta$-galactosidase (Aspergillus oryzae), $\alpha$-galactosidase (coffee beans), $\beta$-glucosidase $/ \beta$-mannosidase (almonds), $\alpha$-glucosidase (yeast) and $\alpha$-mannosidase (jackbeans), however, unfortunately the activities were found to be poor except for $\mathbf{8 5}$ which showed moderate inhibition of $\beta$-galactosidase $(\mathrm{K} / \mu \mathrm{M}=$ $129, \beta$-galactoidase). ${ }^{[46]}$

\section{Synthesis of Castanospermine- type Azasugars}

After having successfully used $\alpha$-trimethylsilylmethylamine radical cation cyclization with tethered olefin to synthesize polyhydroxylated piperdines and their analogues, we turned our attention towards applying this strategy to synthesize the indolizidine class of polyhydroxylated 1-azabicyclo[4.3.0]nonane alkaloids such as castanospermine, swainsonine and other structurally related compounds (Fig. 9).[47] The structural difference between these classes of compounds and 1-deoxynojirimycin is only the presence

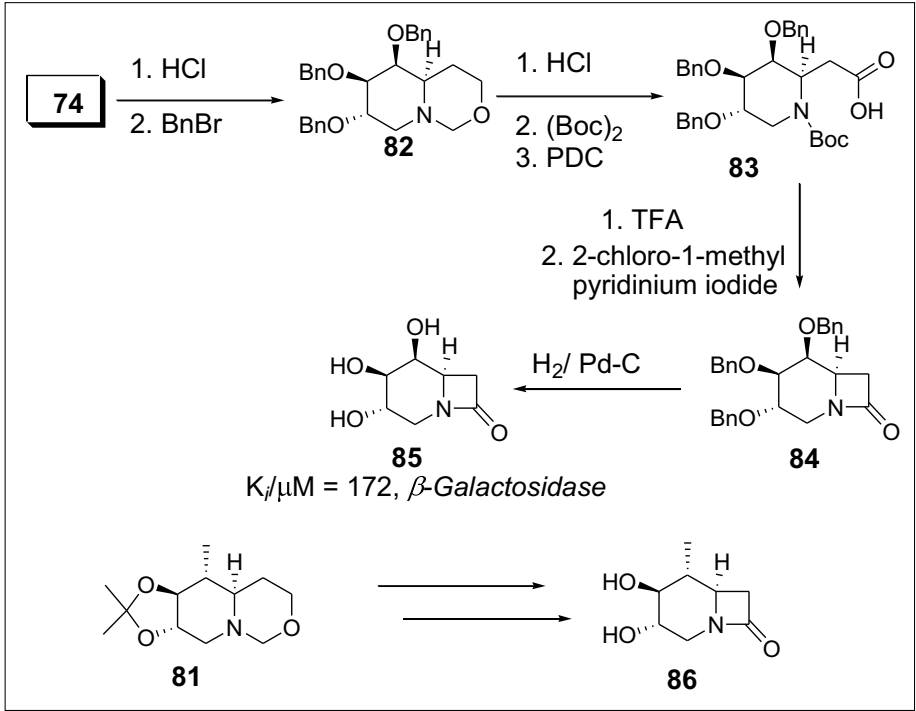

Scheme 15. Synthesis of conformationally restricted polyhydroxy piperidines.

of an ethylene bridge between the nitrogen ring junction and the hydroxymethyl group. These compounds are known to exhibit glucosidase inhibitory activities and some of them have also shown antiviral properties. ${ }^{[48]}$ Since castanospermine on further study was found to cause osmotic diarrhoea $^{[49]}$ attempts have been intensified to synthesize functional analogues of this molecule to overcome this problem. Therefore, various stereoisomers of castenospermine were synthesized, ${ }^{[50]}$ however, the synthetic steps were too long and low yielding. This encouraged us to take up a general route towards the synthesis of these compounds employing our cyclization strategy. It was anticipated that intermediate 96 can be utilized for various structural manipulations by employing a simple synthetic sequence. This intermediate was easily synthesized by PET cyclization of 95 by following the reaction sequences outlined in Scheme 16. Further, functional group manipulations provided 1-deoxy-8-epi-castanospermine 91 in excellent yield. The corresponding amino analogue 93 was also synthesized from 98 as depicted in Scheme 16. Glycosidase inhibitory activities for compounds $\mathbf{9 1 , 9 2}$ and 93 were studied against different enzymes.

Disappointingly all compounds turned out to be inactive against $\alpha$-glucosidase and $\alpha-/ \beta$-mannosidases. 1-Deoxy-8-epicastanospermine 91 showed nonspecific mild inhibition against $\alpha$-galactosidase $(\mathrm{K} /$
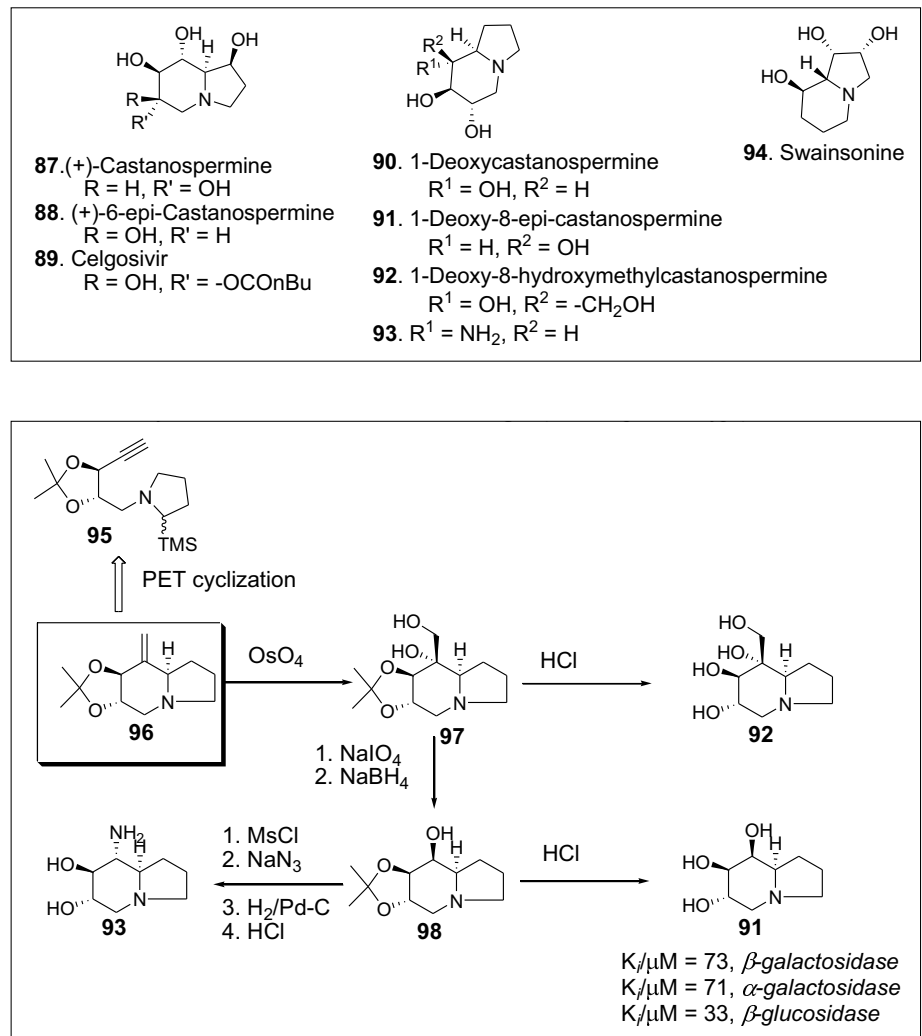

Fig. 9. Indolizidine class of azasugars.

Scheme 16. Synthesis of the indolizidine class of aza sugars(castanospermine type). 
$\mu \mathrm{M}=71, \alpha$-galactoidase), $\beta$-galactosidase $(\mathrm{K} / \mu \mathrm{M}=73, \quad \beta$-galactoidase $)$ and $\beta$-glucosidase $(\mathrm{K} / \mu \mathrm{M}=33, \beta$-glucosidase $)$. We were also disappointed to find that 1-deoxy-8-hydroxymethylcastanospermine 92 and 93 displayed very weak inhibitory activity. ${ }^{[51]}$

Although we synthesized various azasugars starting from tartaric acid where the stereochemistry of the two hydroxyl groups was trans, we also became interested in synthesizing another class of azasugars where two hydroxyl groups would be cis. ${ }^{[32,52]}$ Towards this end it was envisioned that there could be two enantiomeric intermediates 105 and ent-105 (Scheme 17) which would lead to the synthesis of these aza-sugars. It was further hoped that these two intermediates would arise from the PET cyclization of $\mathbf{1 0 3}$ and 104, respectively. We envisioned that these two irradiation precursors could be made available via regio- and stereoselective installation of an acetylenic moiety into D-ribose. In pursuit of the intermediate $\mathbf{1 0 5}$, we prepared 99 by known literature procedures, ${ }^{[53]}$ and the acetylene moiety was installed using Ohira-Bestmann reagent to produce $\mathbf{1 0 2}$. Coupling of 102 with benzylsilylmethylamine produced irradiation precursor $\mathbf{1 0 3}$.

However, cyclization of $\mathbf{1 0 4} \rightarrow \mathbf{1 0 5}$ (60\% yield) indeed, produced unexpectedly $\mathbf{1 0 6}$, confirmed by the crystal structure of $\mathbf{1 0 7}$ produced by its dihydroxylation. Although, it was disappointing initially, this strategy provided intermediate $\mathbf{1 0 7}$ in only six steps compared to a previously described method from tartaric acid (11 steps). The scope of this protocol for synthesizing a number of new azasugar scaffolds was explored and results are summarized in Scheme 18.

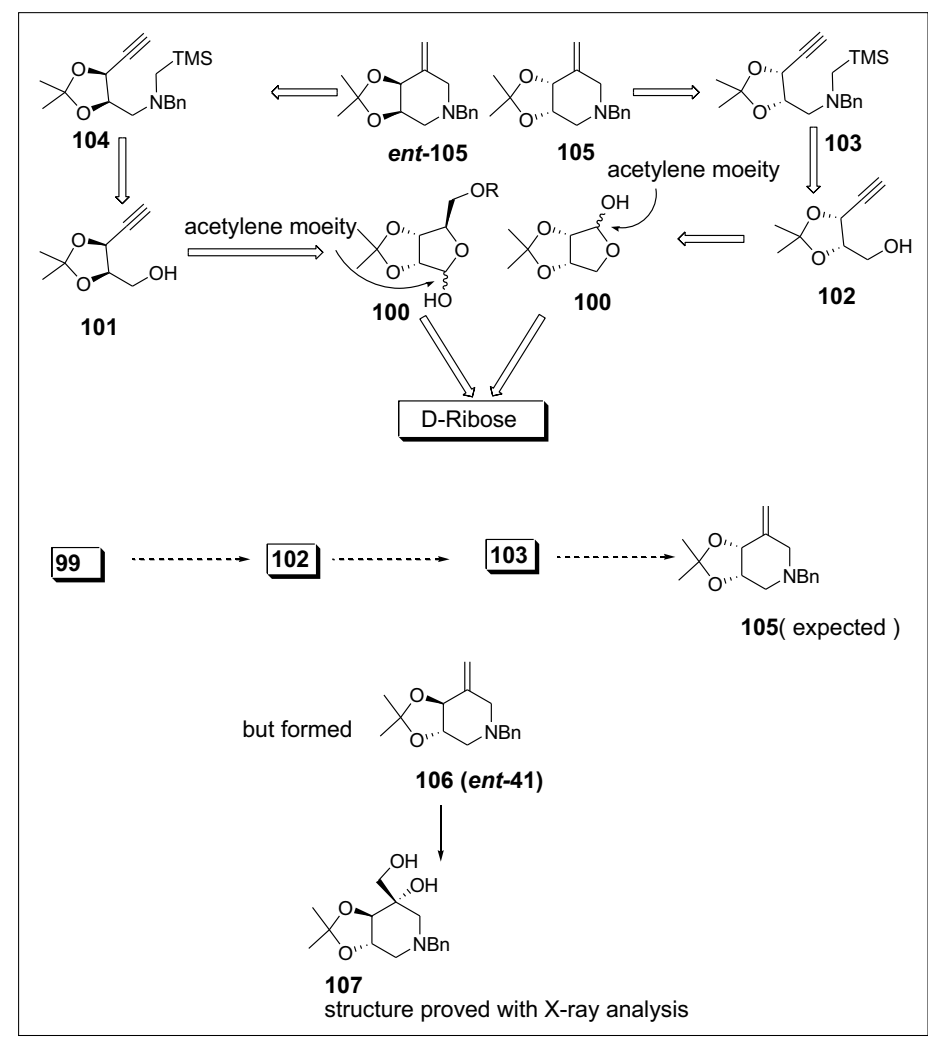

Scheme 17. Improved synthesis of polyhydroxy piperidine type azasugars.
The enzyme inhibition studies for these azasugars were carried out using $\beta$-galactosidase (Aspergillus oryzae), $\alpha$-galactosidase (coffee beans), $\beta$-glucosidase/ $\beta$-mannosidase (almonds), $\alpha$-glucosidase (yeast) and $\alpha$-mannosidase (jackbeans) and all of them showed $\alpha$-glucosidase specific activities. ${ }^{[54]}$ The best result was, however, obtained for compound $110(\mathrm{~K} / \mu \mathrm{M}=1.07, \alpha$-glucosidase $)$.

\section{Synthesis of the Polyhydroxy Quinolizidine Class of Alkaloids}

In order to evaluate further structurereactivity relationships of azasugars possessing azabicyclo[4.4.0]nonane structural frameworks, compounds such as 116-128 were synthesized and evaluated from precursors 129 and 130 which were obtainable by the PET cyclization of $\mathbf{1 3 1}$ and 132, respectively (Scheme 19). Enzyme inhibition studies were performed with these newly synthesized azasugars. ${ }^{[55]}$

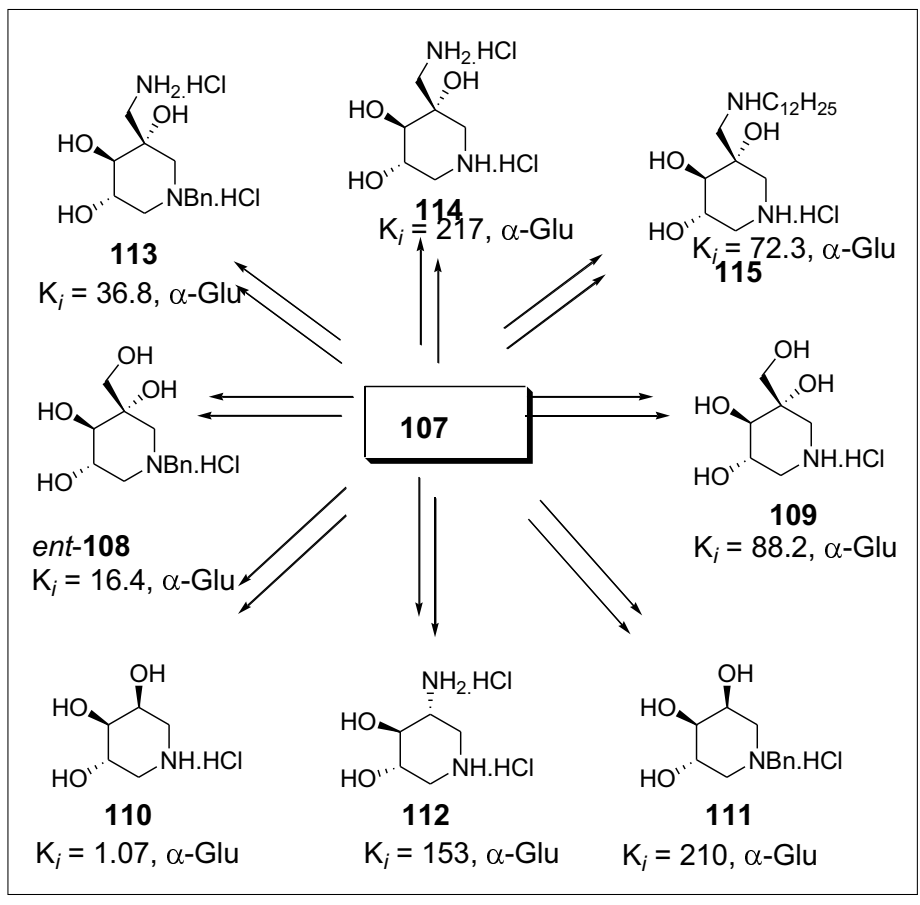

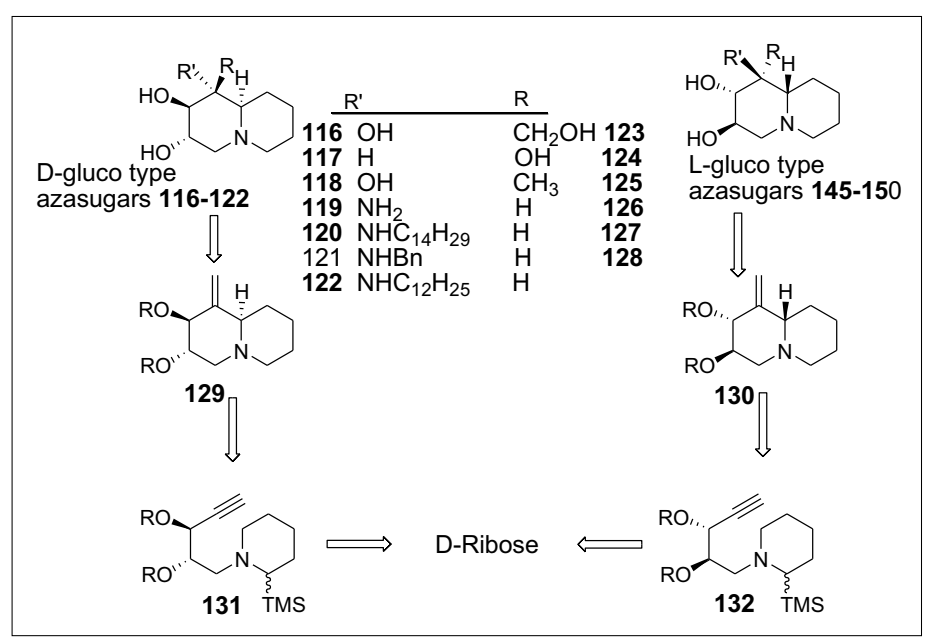

Scheme 19. Synthesis of quinolizidine class of azasugars. 


\section{Conclusion and Outlook}

In summary, we have developed a new concept of $\alpha$-trimethylsilylmethylamine radical cation, generated by photoinduced electron transfer processes, cyclization to tethered olefinic moiety for the synthesis of cyclic amines in general. The chemistry has been explored for the synthesis of stereoselectively substituted pyrrolidines, piperidines, pyrrolizidines, indolizidines and quinolizidines. New as well as known glycosidase inhibitors have been synthesized employing this strategy. It is hoped that this powerful strategy will increasingly find application in the synthesis of structurally complex natural products.

\section{Acknowledgement}

Financial support by DST, New Delhi, is gratefully acknowledged.

Received: January 3, 2013

[1] a) U. Obst, P. Betschmann, C. Lerner, P. Seiler, F. Diederich, Helv. Chim. Acta 2000, 83, 855; b) C. Alvarez-Ibarra, A. G. Csáky, I. Lüpez, M. L. Quiroga, J. Org. Chem. 1997, 62, 479 c) P. Waid, G. A. Flynn, E. W. Huber, J. S Sabol, Tetrahedron Lett. 1996, 37, 4091; d) A Bianco, M. Maggini, G. Scorrano, C. Toniolo, G. Marconi, C. Villani, M. Prato, J. Am. Chem. Soc. 1996, 118, 4072; e) S. A. Kolodziej, G V. Nikiforovich, R. Skeean, M. F. Lignon, J. Martinez, G. R. Marshall, J. Med. Chem. 1995 38,137 ; f) W. H. Pearson, in 'Studies in Natural Product Chemistry', Ed. Atta-Ur-Rahman, Elsevier, New York, 1998, Vol. 1, p. 323; g) P. R. Sebahar, R. M. Williams, J. Am. Chem. Soc. 2000, 122, 5666; h) D. J. Denhart, D. A Griffith, C. H. Heathcock, J. Org. Chem. 1998 63, 9616; i) L. E. Overman, J. E. Tellew, J. Org. Chem. 1996, 61, 8338; j) J. Sisko, J. R. Henry, S. M. Weinreb, J. Org. Chem. 1993, 58, 4945.

[2] a) J. W. Daly, N. Ware, R. A. Saporito, T. F. Spande, H. M. Garraffo, J. Nat. Prod. 2009 72, 1110; b) J. W. Daly, T. F. Spande, H. M. Garraffo, J. Nat. Prod. 2005, 68, 1556; c) J. W. Daly, J. Nat. Prod. 1998, 61, 162; d) J. W. Daly, Proc. Natl. Acad. Sci. 1995, 92, 9.

[3] a) T. M. Gloster, G. J. Davies, Org. Biomol. Chem. 2010, 8, 305; b) N. Asano, Glycobiology 2003, 13, 93R

[4] a) L. Ratner, N. V. Heyden, D. Dedera, Virology 1991, 181, 180 and references therein; b) P. B. Anzeveno, L. J. Creemer, J. K. Daniel, C.-H. R King, P. S. Liu, J. Org. Chem. 1989, 54, 2539 c) J. A. Balfour, D. McTavish, Drugs 1993, 46, 1025; d) N. Zitzman, A. S. Mehta, S. Carroueé T. D. Butters, F. M. Platt, J. McCauley, B. S Blumberg, R. A. Dwek, T. M. Block, PNAS 1999, 96, 11878; e) P. E. Gross, M. A. Baker, J P. Carver, J. W. Dennis, Clin. Cancer Res. 1995 , 1, 935; f) J. Alper, Science 2001, 291, 2338

[5] For piperidine syntheses, see: a) M. Amat, N. r. Llor, J. Hidalgo, C. Escolano, J. Bosch, J. Org. Chem. 2003, 68, 1919; b) P. M. Weintraub, J. S. Sabol, J. M. Kane, D. R. Borcherding, Tetrahedron 2003, 59, 2953; c) M. G. P. Buffat, Tetrahedron 2004, 60, 1701; d) T. Honda, R Takahashi, H. Namiki, J. Org. Chem. 2004 70, 499; e) C. Escolano, M. Amat, J. Bosch, Chem. Eur. J. 2006, 12, 8198; f) H. Yang, R G. Carter, L. N. Zakharov, J. Am. Chem. Soc. 2008, 130, 9238; g) T. K. Beng, R. E. Gawley, J. Am. Chem. Soc. 2010, 132, 12216; h) J Cabrera, T. Hellmuth, R. Peters, J. Org. Chem.
2010, 75, 4326; i) G. Cheng, X. Wang, D. Su, H. Liu, F. Liu, Y. Hu, J. Org. Chem. 2010, 75, $1911 ;$ j) M. K. Ghorai, S. Halder, R. K. Das, $J$. Org. Chem. 2010, 75, 7061; k) N. Coia, N. m. Mokhtari, J.-L. Vasse, J. Szymoniak, Org. Lett. 2011, 13, 6292; 1) G. Guerlet, T. Spangenberg, A. Mann, H. Faure, M. Ruat, Bioorg. Med. Chem. Lett. 2011, 21, 3608; m) M. Nagaraj, M. Boominathan, S. Muthusubramanian, N. Bhuvanesh, Org. Biomol. Chem. 2011, 9, 4642; n) Y. Ying, H. Kim, J. Hong, Org. Lett. 2011, 13, 796; o) S.-L. Zhou, J.-L. Li, L. Dong, Y.C. Chen, Org. Lett. 2011, 13, 5874; p) B. Anxionnat, B. Robert, P. George, G. Ricci, M.-A. Perrin, D. Gomez Pardo, J. Cossy, J. Org. Chem. 2012, 77, 6087; q) T. Kobayashi, F. Hasegawa, Y. Hirose, K. Tanaka, H. Mori, S. Katsumura, J. Org. Chem. 2012, 77, 1812; r) G. Lemonnier, A. B. Charette, J. Org. Chem. 2012, 77, 5832; s) C. Matassini, S. Mirabella, A. Goti, F. Cardona, Eur. J. Org. Chem. 2012, 2012, 3920; t) M. Sakairi, M. Kogami, M. Torii, H. Kataoka, H. Fujieda, M. Makino, D. Kataoka, R. Okamoto, T. Miyazawa, M. Okabe, M. Inoue, N. Takahashi, S. Harada, N. Watanabe, Bioorg. Med. Chem. Lett. 2012, 22, 5123.

[6] For pyrrolidine syntheses, see: a) L. M. Harwood, I. A. Lilley, Tetrahedron: Asymmetry 1995, 6, 1557; b) G. Han, M. G. LaPorte, J. J. Folmer, K. M. Werner, S. M. Weinreb, J. Org. Chem. 2000, 65, 6293; c) B. M. Kenda, A. C. Matagne, P. E. Talaga, P. M. Pasau, E. Differding, B. n. d. I. Lallemand, A. M. Frycia, F. G. Moureau, H. V. Klitgaard, M. R. Gillard, B. Fuks, P. Michel, J. Med. Chem. 2003, 47, 530; d) S. B. Jones, B. Simmons, D. W. C. MacMillan, J. Am. Chem. Soc. 2009, 131, 13606; e) J. Kim, J. S. Schneekloth, E. J. Sorensen, Chem. Sci. 2012, 3, 2849; f) T. Li, J. Liang, A. Ambrogelly, T. Brennan, G. Gloor, G. Huisman, J. Lalonde, A. Lekhal, B. Mijts, S. Muley, L. Newman, M. Tobin, G. Wong, A. Zaks, X. Zhang, J. Am. Chem. Soc. 2012, 134 , 6467.

[7] For pyrrolizidine, indolizidine and quinolizidine syntheses, see: a) T. G. Back, K. Nakajima, $J$. Org. Chem. 2000, 65, 4543; b) J. M. Harris, A. Padwa, J. Org. Chem. 2003, 68, 4371; c) N. C. Mancey, N. Sandon, A.-L. Auvinet, R. J. Butlin, W. Czechtizky, J. P. A. Harrity, Chem. Commun. 2011, 47, 9804; d) I. de Miguel, M. Velado, B. Herradón, E. Mann, Eur. J. Org. Chem. 2012, 4347; e) L. Gomez, X. Garrabou, J. Joglar, J. Bujons, T. Parella, C. Vilaplana, P. J. Cardona, P. Clapes, Org. Biomol. Chem. 2012, 10, 6309.

[8] For selected reviews on cyclic amines, see: a) V. Baliah, R. Jeyaraman, L. Chandrasekaran, Chem. Rev. 1983, 83, 379; b) P. M. Weintraub, J. S. Sabol, J. M. Kane, D. R. Borcherding, Tetrahedron 2003, 59, 2953; c) M. G. P. Buffat, Tetrahedron 2004, 60, 1701; d) I. Nakamura, Y. Yamamoto, Chem. Rev. 2004, 104, 2127; e) G. Pandey, P. Banerjee, S. R. Gadre, Chem. Rev. 2006, 106, 4484

[9] a) W. R. Bowman, M. O. Cloonan, A. J. Fletcher, T. Stein, Org. Biomol. Chem. 2005, 3, 1460; b) F. Denes, F. Beaufils, P. Renaud, Org. Lett. 2007, 9, 4375; c) K. Vervisch, M. D'Hooghe, K. W. Tornroos, N. De Kimpe, Org. Biomol. Chem. 2012, 10,3308

[10] A. Padwa, H. Nimmesgern, G. S. K. Wong, J. Org. Chem. 1985, 50, 5620.

[11] J.-I. Yoshida, T. Maekawa, T. Murata, S.-I. Matsunaga, S. Isoe, J. Am. Chem. Soc. 1990, $112,1962$.

[12] a) G. Pandey, A. Krishna, J. M. Rao, Tetrahedron Lett. 1986, 27, 4075; b) G. Pandey, G. Kumaraswamy, A. Krishna, Tetrahedron Lett. 1987, 28, 2649; c) G. Pandey, G. Kumaraswamy, Tetrahedron Lett. 1988, 29, 4153; d) G. Pandey, Topics in Current Chem. 1993, 168, 175.
[13] G. Pandey, G. Kumaraswamy, U. T. Bhalerao, Tetrahedron Lett. 1989, 30, 6059.

[14] A. L. J. Beckwith, Tetrahedron, 1981, 37, 3073.

[15] G. Pandey, G. D. Reddy, Tetrahedron Lett. 1992, 33, 6533 .

[16] G. Pandey, G. Devi Reddy, G. Kumaraswamy, Tetrahedron 1994, 50, 8185 .

[17] G. Pandey, D. Chakrabarti, Tetrahedron Lett. 1996, 37, 2285.

[18] See ref. [5], [6], [7] and [8] for more details.

[19] a) D. J. Hart, Y. M. Tsai, J. Am. Chem. Soc. 1962, 104, 1430 .

[20] H. Hiemstra, M. H. A. M. Sno, R. J. Vijn, W. N. Speckamp, J. Org. Chem. 1985, 50, 4014.

[21] A. E. Stutz, 'Iminosugars as Glycosidase Inhibitors: Nojirimycin and Beyond', WileyVCH, Weinheim, 1999.

[22] N. Asano, R. J. Nash, R. J. Molyneux, G. W. J. Fleet, Tetrahedron:Asymmetry, 2000, 11, 1645.

[23] a) B. Ganem, Acc. Chem. Res. 1996, 29, 340 b) P. Sears, C.-H. Wong, Angew. Chem. Int. Ed. 1999, 38, 2300; c) T. D. Heightman, A. T. Vasella, Angew. Chem. Int. Ed. 1999, 38, 750.

[24] R. A. Dwek, Chem. Rev. 1996, 96, 683.

[25] a) A. B. Hughs, A. J. Rudge, Nat. Prod. Rep. 1994, 35; b) L. Ratner, N. V. Heyden, D. Dedera, Virology 1991, 181, 180 and references cited therein; c) P. E. Gross, M. A. Baker, J. P. Carver, J. W. Dennis, Clin. Cancer Res. 1995 , 1, 935; d) P. B. Anzeveno, L. J. Creemer, J. K. Daniel, C.-H. R. King, P. S. Liu, J. Org. Chem. 1989, 54, 2539; e) J. A. Balfour, D. McTavish, Drugs 1993, 46, 1025; f) V.-D. Le, C.-H. Wong, J. Org. Chem. 2000, 65, 2399 and references cited therein.

[26] a) T. M. Jespersen, W. Dong, M. R. Sierks, T. Skrydstrup, I. Lundt, M. Bols, Angew. Chem., Int. Ed. Engl. 1994, 33, 1778; b) T. M. Jespersen, M. Bols, M. R. Sierks, T. Skrydstrup, Tetrahedron 1994, 50, 13449.

[27] a) Y. Ichikawa, Y. Igarashi, M. Ichikawa, Y Suhara, J. Am. Chem. Soc. 1998, 120, 3007; b) Y. J. Kim, M. Ichikawa, Y. Ichikawa, J. Org. Chem. 2000, 65, 2599.

[28] G. Pandey, M. Kapur, Tetrahedron Lett. 2000, 41,8821 .

[29] V. H. Lillelund, H. H. Jensen, X. Liang, M Bols, Chem. Rev. 2002, 102, 515 .

[30] For some recent syntheses, see: a) J. Andersch, M. Bols, Chem. Eur. J. 2001, 7, 3744 and references therein; b) G. Zhao, U. C. Deo, B. Ganem, Org. Lett. 2001, 3, 201; c) G. Mehta, N. Mohal, Tetrahedron Lett. 2000, 41, 5747; d) H. Liu, X. Liang, H. Søhoel, A. Bülow, M. Bols, J. Am. Chem. Soc. 2001, 123, 5116; e) X. Liang, A. Lohse, M. Bols, J. Org. Chem. 2000 , 65,7432 ; f) H. Søhoel, X. Liang, M. Bols, J. Chem. Soc., Perkin Trans. 1 2001, 1584.

[31] V. H. Lillelund, H. H. Jensen, X. Liang, M. Bols, Chem. Rev. 2002, 102, 515.

[32] T. Sekioka, M. Shibano, G. Kusano, Nat. Med. 1995, 49, 332

[33] E. Truscheit, W. Frommer, B. Junge, L. Muller, D. D. Schmidt, W. Wigender, Angew. Chem. Int. Ed. 1981, 20, 744.

[34] R. C. Bernotas, G. Papendreou, J. Urbach, B. Ganem, Tetrahedron Lett. 1990, 31, 3393.

[35] a) T. Tschamber, F. Backenstrass, M. Neuburger, M. Zehnder, J. Streith, Tetrahedron, 1994, 50, 1135; b) G. Legler, A. E. Stütz, H. Immich, Carbohydr. Res. 1995, 272, 17; c) M. Godskesen, I. Lundt, R. Madsen, B. Winchester, Bioorg. Med. Chem. 1996, 4, 1857; d) D. Sames, R. Polt, Synlett 1995, 552; e) M. Amat, N. Llor, M. Huguet, E. Molins, E. Espinosa, J. Bosch, Org. Lett. 2001, 3, 3257; f) N. T. Patil, S. John, S. G. Sabharwal, D. D. Dhawale, Bioorg. Med. Chem. 2002, 10, 2155.

[36] a) G. Pandey, M. Kapur, Synthesis 2001, 1263; b) G. Pandey, M. Kapur, Org. Lett. 2002, 4, 3883 . 
[37] G. Pandey, M. Kapur, M. Islam Khan, S. M. Gaikwad, Org. Biomol. Chem. 2003, 1, 3321.

[38] a) T. Niwa, S. Inouye, T. Tsuruoka, Y. Koaze, T. Niida, Agric. Biol. Chem. 1970, 34, 966; b) G. Legler, E. Julich, Carbohydr. Res. 1984, 128, 61 ; c) A. E. Stutz, 'Iminosugars as glycosidase inhibitors: nojirimycin and beyond', WileyVCH, Weinheim, Germany, 1999

[39] a) M. S. M. Pearson, M. Mathé-Allainmat, V. Fargeas, J. Lebreton, Eur. J. Org. Chem. 2005 , 2159 ; b) A. Kato, N. Kato, E. Kano, I. Adachi, K. Ikeda, L. Yu, T. Okamoto, Y. Banba, H. Ouchi, H. Takahata, N. Asano, J. Med. Chem. 2005, 48, 2036; c) K. Afarinkia, A. Bahar, Tetrahedron: Asymmetry 2005, 16, 1239.

[40] a) A. Mitrakou, N. Tountas, A. E. Raptis, R. J. Bauer, H. Schulz, S. A. Raptis, Diabetic Med. 1998, 15, 657; b) L. J. Scott, C. M. Spencer, Drugs 2000, 59, 521.

[41] a) L. A. Sorbera, J. Castaner, M. Bayes, Drugs Fut. 2003, 28, 229; b) P. L. McCormack, K. L. Goa, Drugs 2003, 63, 2427; c) T. M. Cox, J. M. F. G. Aerts, G. Andria, M. Beck, N. Belmatoug, B. Bembi, R. Chertkoff, S. Vom Dahl, D. Elstein, A. Erikson, M. Giralt, R. Heitner, C. Hollak, M. Hrebicek, S. Lewis, A. Mehta, G M. Pastores, A. Rolfs, M. C. Sa Miranda, A. Zimran, J. Inherited Metab. Dis. 2003, 26, 513.

[42] a) A. Kilonda, F. Compernolle, S. Toppet, G. J Hoornaert, Tetrahedron Lett. 1994, 35, 9047; b) N. N. Saha, V. N. Desai, D. D. Dhavale, Tetrahedron 2001, 57, 39; c) N. T. Patil, J. N. Tilekar, D. D. Dhavale, J. Org. Chem. 2001, 66,1065 ; d) V. N. Desai, N. N. Saha, D. D. Dhavale, Chem. Commun. 1999, 1719; e) D. D. Dhavale, M. M. Matin, T. Sharma, T.; Sabharwal, S. G. Bioorg. Med. Chem. 2003 11, 3295; f) P. Szolcsányi, T. Gracza, M. Koman, N. Prónayová, T. Liptaj, Tetrahedron: Asymmetry 2000, 11, 2579; g) P. Szolcsányi,
T. Gracza, M. Koman, N. Prónayová, T. Liptaj, Chem. Commun. 2000, 471; h) C. Herdeis, T. Schiffer, Tetrahedron 1996, 52, 14745; i) M. Achmatowicz, L. S. Hegedus, J. Org. Chem. 2004, 69, 2229.

[43] a) Y. Nishimura, H. Adachi, T. Satosh, E. Shitara, H. Nakamura, F. Kojima, T. Takeuchi, J. Org. Chem. 2000, 65, 4871; b) V. H. Lillelund, H. Liu, X. Liang, H. Søhoel, M. Bols, Org. Biomol. Chem. 2003, 1, 282; c) M. I. Garcia-Moreno, D. Rodriguez-Lucena, C. Ortiz Mellet, J. M. Garcia Fernandez, J. Org. Chem. 2004, 69, 3578; d) P. Diaz Perez, M. I. Garcia-Moreno, C. Ortiz Mellet, J. M. Garcia Fernandez, Eur. J. Org. Chem. 2005, 2903.

[44] a) A. Sygula, J. Chem. Res. 1989, 56; b) S. J. Williams, V. Notenboom, J. Wicki, D. R. Rose, S. G. Withers, J. Am. Chem. Soc. 2000, 122, 4229.

[45] G. Pandey, S. G. Dumbre, M. I. Khan, M. Shabab, J. Org. Chem. 2006, 71, 8481 .

[46] G. Pandey, S. G. Dumbre, M. I. Khan, M. Shabab, V. G. Puranik, Tetrahedron Lett. 2006, 47, 7923.

[47] a) L. D. Hohenschutz, E. A. Bell, P. J. Jewess, D. P. Leworthy, R. J. Pryce, E. Arnold, J. Clardy, Phytochemistry 1981, 20, 811; b) R. J. Nash, L. E. Fellows, J. V. Dring, C. H. Stirton, D. Carter, M. P. Hegarty, E. A. Bell, Phytochemistry 1988, 27, 1403; c) S. M. Colegate, P. R. Dorling, C. R. Huxtable, Aust. J. Chem. 1979, 32, 2257.

[48] a) N. Asano, A. Kato, A. A. Watson, Mini-rev. Med. Chem. 2001, 1, 145; b) E. De Clercq, Med. Res. Rev. 2000, 20, 323; c) P. Cos, D. Vanden Berghe, T. De Bruyne, A. J. Vlietinck, Curr. Org. Chem. 2003, 7, 1163; d) K. Whitby, T. C. Pierson, B. Geiss, K. Lane, M. Engle, Y. Zhou, R. W. Doms, M. S. J. Diamond, Virol. 2005, 79, 8698 .
[49] K. M. Robinson, B. L. Rhinehart, J.-B. Ducep, C. Danzin, Drugs Fut. 1992, 17, 705 .

[50] a) K. Burgess, I. Henderson, Tetrahedron 1992 , 48, 4045; b) H. Yoda, Curr. Org. Chem. 2002, 6 , 223 ; c) D. Hendry, L. Hough, A. C. Richardson, Tetrahedron 1988, 44, 6143; d) K. H. Aamlid, L. Hough, A. C. Richardson, Carbohydr. Res. 1990, 202, 117; e) Y. St-Denis, T. H. Chan, J. Org. Chem. 1992, 57, 3078; f) H. Yoda, T. Nakajima, K. Takabe, Synlett 1997, 911; g) H. Zhang, Y. K. Ni, G. Zhao, Y. Ding, Eur. J. Org. Chem. 2003, 1918; h) A. I. Meyers, D. A. Price, Chirality 1998, 10, 88; i) N. S. Karanjule, S D. Markad, T. Sharma, S. G. Sabharwal, V. G. Puranik, D. D. Dhavale, J. Org. Chem. 2005, 70, 1356; j) D. D. Dhavale, S. M. Jachak, Molecules 2005, 10, 893; k) N. T. Patil, J. N. Tilekar, D. D. Dhavale, Tetrahedron Lett. 2001, 42, 747; k) A. M. P. Koskinen, O. A. Kallatsa, Tetrahedron 2003, 59, 6947; 1) F. Chevallier, E. L. Grognec, I. Beaudet, F. Fliegel, M. Evain, J.-P. Quintard, Org. Biomol. Chem. 2004, 2, 3128.

[51] G. Pandey, S. G. Dumbre, S. Pal, M. I. Khan, M. Shabab, Tetrahedron 2007, 63, 4756.

[52] Y. Ichikawa, Y. Igarashi, Tetrahedron Lett. $\mathbf{1 9 9 5}, 36,4585$

[53] a) H. Kotsuki, T. Araki, A. Miyazaki, M. Iwasaki, P. K. Datta, Org. Lett. 1999, 1, 499502; b) S. Muller, B. Liepold, G. J. Roth, H Bestmann, Synlett 1996, 521; c) G. J. Roth, B. Liepold, S. Muller, H. Bestmann, Synthesis 2004, 59; d) J. Pietruszka, A. Witt, Synthesis 2006, 4266.

[54] G. Pandey, K. C. Bharadwaj, M. I. Khan, K. S. Shashidhara, V. G. Puranik, Org. Biomol. Chem. 2008, 6, 2587.

[55] G. Pandey, D. Grahacharya, K. S. Shashidhara, M. I. Khan, V. G. Puranik, Org. Biomol. Chem. 2009, 7, 3300 . 